\title{
Construction of the Deep School-enterprise Cooperation Mechanism in E-commerce
}

\author{
Haiyan Bian \\ School of Information Science and Technology \\ Taishan University \\ Taian, China \\ xkxhaiyan@163.com
}

\author{
Wenling Liu \\ School of Information Science and Technology \\ Taishan University \\ Taian, China \\ 1002653637@qq.com
}

\begin{abstract}
School-enterprise cooperation is a "win-win" mode, which realizes the sharing of information and resources, complementary advantages, and saves the cost of education and enterprises. However, there are still many problems in the schoolenterprise cooperation, such as the lack of willingness of enterprises to participate, low cooperation level, the lack of effective schoolenterprise cooperation mechanism, etc. Taking the e-commerce specialty as an example, this paper analyzes of the necessity and current situation of the school-enterprise cooperation, and puts forward the construction of school-enterprise cooperation mechanism from three aspects to promote the development of professional-school enterprise cooperation in e-commerce.
\end{abstract}

\section{Keywords-E-commerce; School-enterprise Cooperation; Cooperation Mechanism}

\section{INTRODUCTION}

School-enterprise cooperation is a market-oriented model with mutual benefit and win-win in personnel training, scientific research, technology research and development, production management, resource sharing, information communication, etc. [1]. Both sides of the school and enterprise should work out the training and teaching plan, arrange the teaching content, evaluate the teaching achievement and do the educational management work according to their own needs. The deep school-enterprise cooperation is a close cooperation between schools and enterprises. Through the cooperation, the school can be cultivate applied talents to meet the social and business needs based on the market orientation and the enterprise can use the idle knowledge and resources at the enterprise development with low cost and high efficiency. School enterprise cooperation is a "win-win" mode through the sharing of information and resource of the school and enterprise, so that the school and enterprise can achieve complementary advantages of equipment and technology and save education and enterprise costs. However, there are still many problems in the school-enterprise cooperation, such as the lack of willingness of enterprises to participate, the communication between school and enterprise, treating students as a cheap labor, the common development of curriculum, the teachers' insufficient ability and the lack of effective guarantee of teaching effect [2]. Therefore, this paper, taking the major of e-commerce as an example, analyzes the present situation of school-enterprise cooperation and constructs the deep cooperation mechanism of ecommerce.

\section{THE NECESSITY OF SCHOOL-ENTERPRISE COOPERATION IN E-COMMERCE}

E-commerce major has a practicability with the internet. It demands students not only strong computer professional knowledge, but also the ability of learning changing knowledge continually and a strong hands-on skills. At present, there are no uniform standards of contents of e-commerce provided in schools, and some of them are too complex to meet the actual needs, which can lead to confusion of students' thinking. Besides, because of the rapid development of e-commerce, it is very fast that the knowledge of e-commerce is updating. As a result, the knowledge the students learn is always fall behind the development of the times. So, it is hardly to put the knowledge they learn in practice flexibly. It pointed out that $75 \%$ e-commerce enterprises had the problem of ecommerce talents shortage in "the 2015 annual survey report of e-commerce personnel status in China" [3]. And one of the core contradiction of e-commerce development is the talents cultivated by the traditional education cannot meet the needs of ecommerce enterprise. It mainly manifests in the following several aspects:

\section{A. The unreasonable curriculum system}

The rapid development of e-commerce requires the ability of strong learning and quickly updating the knowledge. And the current curriculum system cannot guide future work and practice.

\section{B. The insufficient faculty and lack of practical experience of the teachers}

E-commerce is a very practical, and most teachers do not have personal experience .At the same time, they lack the opportunity to communicate with other enterprises, so they cannot give effective guidance and help to students. 


\section{The disconnect between teaching goal and reality}

In school, the teachers and the students just want to complete the studies and finish school and the teaching goal do not really meet the core requirements of e-commerce enterprises.

School-enterprise cooperation, as an important part of the e-commerce practice teaching system, is the key links of cultivating the students' practical ability and innovative spirit, and it is also an important way to solve the structural contradictions of talent supply and demand of the e-commerce. School-enterprise cooperation can achieve seamless docking of schools and enterprises and help enterprises solve the e-commerce talents gap. According to the needs of enterprises, it can establish scientific and reasonable training objectives and training program, set the reasonable curriculum system and allow students to grasp the counterpart of professional skills. Thus, more talents will be cultivated to adapt to the development of enterprises, and the difficult problem will also be solved to the students' employment.

\section{PROBLEMS EXISTING IN SCHOOL-ENTERPRISE COOPERATION OF E-COMMERCE MAJOR}

Because of the lack of effective cooperation mechanism, the school-enterprise cooperation in e-commerce has encountered many difficulties and problems in practice.

\section{A. Lacking of enthusiasm for enterprises}

The purpose of school-enterprise cooperation for enterprises is that schools can deliver the e-commerce professionals to enterprises and the cost of enterprises for its own development is reduced. And enterprises are not interested in participating in school teaching and other activities. This is because enterprises are lack of benefit driven and the state has not promulgated corresponding policies and regulations to regulate and promote many activities involved in school-enterprise cooperation. Besides, it is uncertain that the talents cultivated will work in their enterprises after they graduate, which lead to invest a lot but receive little for enterprises. Moreover, the school's hardware facilities and qualified teachers and other aspects cannot meet the requirements. The substantive progress of school-enterprise cooperation is relatively slow. The schools have high enthusiasm but enterprises don't have one, which result in the loss of initiative and vitality of school-enterprise cooperation.

\section{B. Deficiency of effective school-enterprise cooperation mechanism}

It involves many aspects, such as differences in cultural values, the uneven balance of resources between two sides, lacking of government police guidance and related laws and regulations, poor communication and coordination channels, management of students majoring in e-commerce, assessment of learning performance, distribution of interests and so on [5]. Thus, in the process of school-enterprise cooperation, a standard system is necessary to restrict the two sides of school enterprise, clear responsibilities and obligations and take risks together to assure the interests of both parties. It will provide strong support for promoting the sustainable development of the deep cooperation between enterprises and enterprises in e-commerce.

\section{CONSTRUCTION OF THE DEEP SCHOOL-ENTERPRISE COOPERATION MECHANISM}

This paper puts forward the construction of school-enterprise cooperation mechanism from three aspects to promote the development of professional-school enterprise cooperation in e-commerce.

\section{A. Establishing government regulation and guidance mechanism}

The further development of school-enterprise cooperation cannot do without the policy and legal guarantee. According to the current development of school enterprise cooperation in China, the government should formulate and improve the policies and regulations of school-enterprise cooperation from the strategic level which is conducive to the healthy development of society. The government also should formulate relevant incentive policies. It can actively guide enterprises to participate in the cooperation from policy and provide protection of all parties of school-enterprise cooperation, which lead to a healthy and orderly development of the depth of cooperation and a strong guarantee for schools to train talents who are really good for social development. When formulating policies and regulations, we should comprehensively comb and review the current relevant policies and regulations and introduce the relevant policies and regulations of "the school-enterprise cooperation promotion law" as soon as possible so as to promote the full play of the school-enterprise cooperation.

\section{B. Establishing the resource sharing mechanism}

In the school-enterprise cooperation, the resources superiority of schools and enterprises is unbalanced. Schools have sufficient production force, relatively complete teaching facilities and strong theoretical support. Enterprises have relatively sufficient funds, rich practical experience, and the project and practice platform adapted to the social needs. Only the resources sharing can realize the complementary advantages. Two sides each take what's they need, thus school-enterprise cooperation can run in-depth longterm and stably.

To achieve resource sharing, at first, the school can cultivate e-commerce professional management and operation talents and high-skilled talents through the establishment of "Entrepreneurship class" or "studio". In the process of cooperation, when the 
enterprises at the peak of the operation, such as November 11, the school can adjust the teaching plan in time, implement flexible credit system and take the "post- practice" mode. As long as the students meet the credit requirements on schedule, they can apply for internships in enterprises. In addition, schools can also send professional teachers to enterprises to give theoretical and technical guidance to students or enterprise project activities, to meet the needs of the enterprise and increasing teacher's practical experience to further enhance the education ability and level.

\section{Establishing effective communication and coordination mechanism}

It is a reliable guarantee to establish an effective communication and cooperation mechanism for the smooth progress of schoolenterprise cooperation. First of all, it is necessary to strengthen exchanges between the two sides through a variety of channels such as regular organization of visiting enterprises and knowing the needs of enterprises, and making scientific research activities more innovative and practical significance [6]. Secondly, the "enterprise expert" and "technical backbone" can be invited to the campus to organize various e-commerce seminars, expert forums and so on, and communicate with students to close the distance between students and enterprises. Thirdly, schools and enterprises connection can be improved through the project cooperation. Enterprises can get e-commerce Commissioner Supplement and technical support from school and the school can obtain practical experience from enterprises, which is called "win-win". Fourthly, regular school-enterprise exchange meeting of e-commerce will be held to discuss the problems schools and enterprises encountered in the development of e-commerce. Only in this way can schools can know the e-commerce industry information in time, grasp the direction of e-commerce development and talent demand situation, and adjust teaching plans promptly to transport talents enterprises needed.

\section{CONCLUSIONS}

It is an important way and an inevitable choice that strengthening the deep school-and enterprise cooperation to enhance their ability of sustainable development for schools, students and enterprises. Both schools and enterprises must truly form a set of effective long-term mechanism to lay a solid foundation for the school-enterprise cooperation.

\section{REFERENCES}

[1] Huashu Li, Chong Ye, "The basic framework of regional cooperation and development of higher education in China -- implications for the construction of higher education zones in Europe," Research on educational development. vol.21, pp. 7-12, 2015.

[2] Jun Li, "Research on key institutional factors of enterprise participation in vocational education -- based on the analysis of new institutional economics," Jiangsu higher education. vol.1, pp. 85-89, January 2017.

[3] Information on http://www.100ec.cn/zt/upload_data/B2B/rc.pdf.

[4] Zhenhong Wang, "Uniqueness and construction path of teacher cultures in higher vocational education," China Education Daily. pp. 09-23, 2010.

[5] Wenhui Zhou, "Dilemma and strategy of the deep integration of colleges and enterprises in applied universities," Jiangxi social sciences. vol.36, pp. 252-256, 2016.

[6] Lige Zhang, Pengxiang Tang, "Research on the development of school enterprise cooperation in research universities," Higher education exploration. vol.5, pp. 33-37, January 2016. 